\title{
Pyrolyzed iron-cobalt/polyaniline on bentonite clay as electrocatalyst for oxygen reduction reaction
}

\author{
Hannah Grace D. Geronimo ${ }^{1,3}$, Jonyl L. Garcia ${ }^{1,3,4}$, \& Bernard John V. Tongol ${ }^{1,2,3 *}$
}

${ }^{1}$ The Graduate School; ${ }^{2}$ Department of Chemistry, College of Science; ${ }^{3}$ Research Center for the Natural and Applied Sciences, University of Santo Tomas, España Boulevard, 1015 Manila, The Philippines

${ }^{4}$ Chemistry Department, College of Science, Adamson University, 1000 Manila, The Philippines

\section{Graphical Abstract}
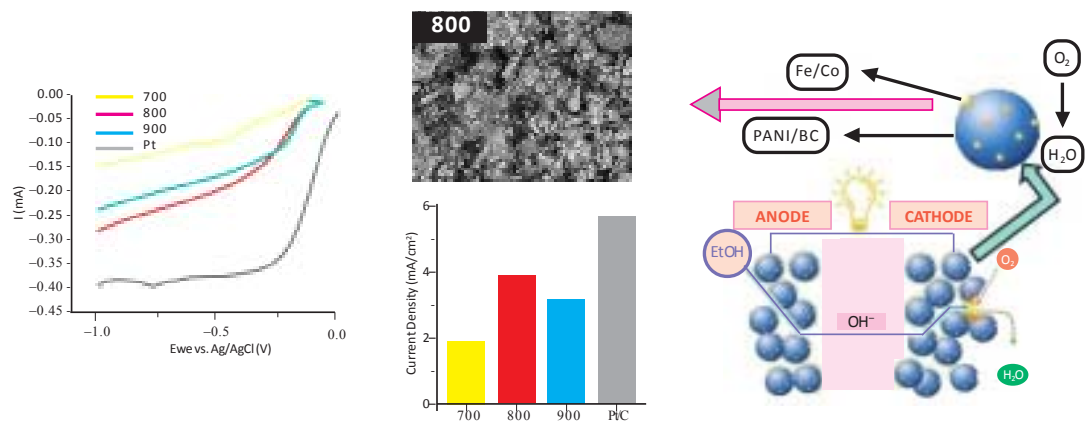

\section{Abstract}

The oxygen reduction reaction (ORR), which is catalyzed by cathode electrocatalysts in polymer electrolyte membrane fuel cells (PEMFCs), is of great interest due to its slow kinetics. Support matrices are known to significantly contribute to the overall performance of ORR electrocatalysts by providing the required porosity and/or conductivity. Although carbon-based materials are usually employed as electrocatalysts support matrices, clays such as bentonite is a promising cheaper alternative due to their high intrinsic porosity. This study investigates the effect of bentonite clay (BC) support matrix on the electrocatalytic activity of pyrolyzed FeCo/PANI towards ORR. Polyaniline (PANI)/ $\mathrm{BC}$ was prepared via in-situ polymerization, followed by re-dispersion in aqueous solutions of iron and cobalt precursors and subsequent reduction with $\mathrm{NaBH}_{4}$ to form $\mathrm{FeCo} / \mathrm{PANI} / \mathrm{BC}$. Pyrolysis of the resulting composites was performed using a tube furnace under $\mathrm{N}_{2}$ atmosphere by heating the electrocatalyst at $700^{\circ} \mathrm{C}, 800^{\circ} \mathrm{C}$, and $900^{\circ} \mathrm{C}$ at a rate of $5^{\circ} \mathrm{C} / \mathrm{min}$. The resulting electrocatalyst was characterized using scanning electron microscopy (SEM), cyclic voltammetry (CV), and rotating disk electrode (RDE) voltammetry. SEM revealed the cauliflower-like morphology of PANI and the welldistributed porous structure of $\mathrm{BC}$. The $\mathrm{CV}$ data in basic condition showed the enhanced electrocatalytic activity of $\mathrm{FeCo} / \mathrm{PANI} / \mathrm{BC}$ at $800^{\circ} \mathrm{C}\left(3.98 \mathrm{~mA} / \mathrm{cm}^{2}\right)$ compared to the catalyst at $700^{\circ} \mathrm{C}$ and $900^{\circ} \mathrm{C}$. $\mathrm{RDE}$ results showed a four-electron pathway for all the catalysts. The results suggest the possibility of utilizing pyrolyzed $\mathrm{FeCo} / \mathrm{PANI} / \mathrm{BC}$ as a cheaper substitute to $\mathrm{Pt} / \mathrm{C}$.

Keywords: ORR, cathode catalyst, bentonite clay, PANI, PEMFC 


\section{INTRODUCTION}

Fuel cells offer a promising renewable and clean energy source as they provide high energy densities and efficiencies compared to other conventional systems [1]. Fuel cells can be classified according to the type of electrolyte used in the cells. Polymer electrolyte membrane fuel cells (PEMFCs) have been recognized as future power sources for zero emission vehicles because it efficiently generates high power density [2]. One type of PEMFC which uses anhydrous or diluted ethanol (EtOH) as fuel is direct ethanol fuel cell (DEFC). EtOH offers a promising fuel for DEFCs because it can be produced in large quantities from biomass and is much less toxic than methanol [3]. The DEFC is, therefore, an energy source with great potential. The kinetics in DEFC is sluggish due to the complete EtOH oxidation requiring 12-electron transfer happening on the anode component. As the anode oxidizes the EtOH fuel, the cathode compartment undergoes an oxygen reduction reaction (ORR) simultaneously. The ORR at the cathode compartment is sluggish and goes through a four-electron transfer for complete reduction [4].

To respond to this dilemma, researchers had developed a way to hasten the reactions occurring at the anode and cathode compartments of fuel cells. Through the synthesis and design of metal-based catalyst, the slow reactions in DEFC had been significantly improved.

The high cost of DEFC due to the high Pt loading is the most important factor that hinders the large-scale commercialization of these kinds of fuel cells [9]. There have been numerous efforts to lower fuel cell costs by minimizing the platinum content in the catalyst layer. Thus, developing an inexpensive non-Pt cathodic catalyst would be a solution for the high cost of DEFC [7].

Previous works [2, 7-12] have provided means to develop low-Pt and even Pt-free catalyst for DEFC. Transition metal/nitrogen/carbon nanomaterial complexes synthesized through pyrolysis are considered one of the most promising routes for improving ORR activity and stability while reducing the catalyst cost [7-12]. This class of non-precious catalysts for cathode which has fascinated the attention of DEFC researchers was first obtained from the pyrolysis of iron porphyrins [2]. The active sites for ORR electrocatalysis on pyrolyzed iron porphyrins are associated with the high nitrogen concentration in porphyrins. Although this class of ORR electrocatalysts exhibited good initial activity, the material still suffers from poor stability and low conductivity [2]. Thus, finding a more stable nitrogen source for the transition metal-nitrogen complexes is an area of active research.

Nitrogen-containing polymers, such as conductive polymers, are used to improve the activity of ORR electrocatalysts. Pyrolysis of these conductive polymers with carbon supports such as carbon nanotubes (CNT) and graphene is a common route found in the literature for the preparation of electrocatalyst for ORR [7-11]. However, these carbon supports are thermally unstable, especially at prolonged exposure to high temperatures [12]. Aside from its thermal instability, carbon supports tend to promote agglomeration due to its hydrophobic character [13], leading to difficulties 
in forming homogeneous dispersions for electrocatalysts inks based on these supports. A study by Debnath and colleagues [13] showed that mineral clays were able to improve ink dispersion because it readily dissociates itself in the composite matrix.

Mineral clays have high cation-exchange capacity, high electrical conductivity, and large surface area [12-17]. The characteristics of clay makes it a good template for producing carbon-clay nanocomposites after pyrolysis. The use of naturally occurring and cheap $\mathrm{SiO}_{2}$-containing hydrophilic bentonite clay (BC) is an eco-friendly method without using reducing agents [15]. The clay enhanced with conductive polymer are carbon and nitrogen sources, which are pyrolyzed to form potentially active ORR composites. It can be compared with graphene-like nanomaterials having special properties useful towards ORR [15].

The use of transition metals and conductive polymers with carbon supports as catalyst for PEMFC and other types of fuel cells achieved both activity and stability [7-11]. A cheaper alternative to carbon supports is the focus of the study. Specifically, the study pyrolyzed the $\mathrm{FeCo} / \mathrm{PANI} / \mathrm{BC}$ composite and explored its performance as an ORR electrocatalyst. The use of BC as support material opens the possibility towards cheaper fuel cell electrocatalysts.

\section{Methodology}

Materials and chemicals. Bentonite clay was purchased from Saile Industries (Pangasinan, Philippines), and was treated with deionized (DI) water and dried at $150^{\circ} \mathrm{C}$ for $1 \mathrm{~h}$ prior to use. Chloroplatinic acid hexahydrate $\left(\mathrm{H}_{2} \mathrm{PtCl}_{6} \cdot 6 \mathrm{H}_{2} \mathrm{O}\right)(>99.9 \%)$ was purchased from Merck (Germany). Iron(III) chloride hexahydrate $\left(\mathrm{FeCl}_{3} \cdot 6 \mathrm{H}_{2} \mathrm{O}\right)$, cobalt (II) chloride hexahydrate $\left(\mathrm{CoCl}_{2} \cdot 6 \mathrm{H}_{2} \mathrm{O}\right)$, aniline, sodium borohydride $\left(\mathrm{NaBH}_{4}\right)$, and ammonium peroxydisulfate $\left(\left(\mathrm{NH}_{4}\right)_{2} \mathrm{~S}_{2} \mathrm{O}_{8}\right)$ (APS) with $99 \%$ purity was purchased from Sigma Aldrich (USA) and were used as received.

Synthesis of FeCo/PANI/BC. Aniline $(80 \mathrm{~mL})$ was first dispersed along with $\mathrm{BC}$ in a hydrochloric acid solution $(0.5 \mathrm{M}, 100 \mathrm{~mL})$. APS $(0.20 \mathrm{~g})$ and the transition metal precursor $\mathrm{FeCl}_{3} \cdot 6 \mathrm{H}_{2} \mathrm{O}(3 \mathrm{mM})$ and $\mathrm{CoCl}_{2} \cdot 6 \mathrm{H}_{2} \mathrm{O}(3 \mathrm{mM})$ were added dropwise into the mixture while the temperature was kept below $10^{\circ} \mathrm{C}$. The molar ratio of aniline to APS is $1: 1 . \mathrm{NaBH}_{4}$ was then added in order to reduce the metal salts into metallic Fe and Co. After 24 h of continuous mixing, the resulting mixture was then filtered, washed, and dried in an oven at $60^{\circ} \mathrm{C}[18]$. The dried powder was pyrolyzed at $700^{\circ} \mathrm{C}, 800^{\circ} \mathrm{C}$, and $900^{\circ} \mathrm{C}$ for $1 \mathrm{~h}$ under $\mathrm{N}_{2}$ flow [19].

Instrumentation. All electrochemical measurements were performed using a threeelectrode system at room temperature, using a Pt wire and a $\mathrm{Ag} / \mathrm{AgCl}$ (saturated with $3 \mathrm{M} \mathrm{KCl}$ ) electrode as the counter and reference electrodes, respectively. The working electrodes used were $\mathrm{FeCo} / \mathrm{PANI} / \mathrm{B}$ pyrolyzed catalyst inks at $700^{\circ} \mathrm{C}, 800^{\circ} \mathrm{C}$, and $900^{\circ} \mathrm{C}$, which were drop-casted on a glassy carbon electrode (GCE). The catalyst ink was prepared by mixing $1 \mathrm{mg}$ of the catalyst powder with $980 \mu \mathrm{L} \mathrm{N}, \mathrm{N}-$ dimethylformamide (DMF), and $20 \mu \mathrm{L}$ Nafion solution (DuPont D521). The GCE was 
first polished using emery paper (grade 1200-1500) and alumina. All electrochemical measurements were carried out using a potentiostat (EDAQ, Australia) manipulated by a software system (EChem, EDAQ). The surface morphologies of the synthesized catalysts were investigated using Hitachi TM 3000 Tabletop Microscope with an accelerating voltage of $15 \mathrm{kV}$.

\section{Results AND Discussion}

\section{Electrochemical characterization of pyrolyzed FeCo/PANI/BC catalyst with commercially available Pt/C catalyst}

Cyclic voltammetry (CV) studies. In an alkaline environment, the direct ORR involving $4 \mathrm{e}$ - produces hydroxides (OH-) which is an intermediate of the reaction [20]. According to Senarathna and Rajapakse [17], ORR occurs more suitably in alkaline media, with metals such as $\mathrm{Fe}$ and $\mathrm{Co}$ able to aid in the degradation of hydroxide ions. This situation makes the ORR potential close in value to the theoretical oxygen electrode potential [17]. The CV profiles (Fig. 1) of the various pyrolyzed catalysts in $\mathrm{O}_{2}$ saturated $0.1 \mathrm{M} \mathrm{KOH}$ media are shown. Figure 1 shows that $\mathrm{Pt} / \mathrm{C}$ (in gray solid curve) has the highest $\mathrm{ORR}$ activity compared to $\mathrm{FeCo} / \mathrm{PANI} / \mathrm{BC}$ pyrolyzed at $700^{\circ} \mathrm{C}$ (yellow solid curve), $800^{\circ} \mathrm{C}$ (red solid curve), and $900^{\circ} \mathrm{C}$ (blue solid curve). It also shows the ORR peaks (red-dashed line) of the catalyst composite pyrolyzed at $700^{\circ} \mathrm{C}, 800^{\circ} \mathrm{C}$, and $900^{\circ} \mathrm{C}$, and $\mathrm{Pt} / \mathrm{C}$ (Premetek) composites at $\sim-0.4 \mathrm{~V}$, with onset potentials (blackdashed line) at $\sim-0.2 \mathrm{~V}$. The number of electrons and the current densities were chosen as the basis for comparing the ORR activity of each composites produced at different pyrolysis temperatures.

There are a handful of studies that investigated the utility of clays as support for ORR electrocatalysts [12-17]. These studies showed that the ORR peak for such materials are positioned at approximately $-0.4 \mathrm{~V}[16,17,21]$. Furthermore, this cathodic peak cannot be attributed to the reduction of the conductive polymer since PANI in this study was degraded during pyrolysis. Graphitic structures with N-containing

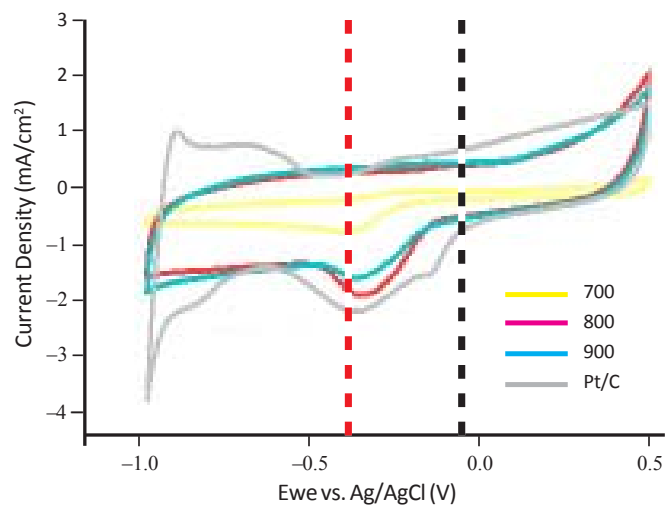

Figure 1. CV Profiles of $\mathrm{FeCo} / \mathrm{PANI} / \mathrm{BC}$ pyrolyzed at different pyrolysis temperatures vs. $\mathrm{Pt} / \mathrm{C}$ (Premetek) in $0.1 \mathrm{M} \mathrm{KOH}$ at $50 \mathrm{mV} / \mathrm{s}$ scan rate. moieties are known to form during the pyrolysis of polypyrrole and PANI [8-11]. These moieties, along with the metallic $\mathrm{Fe}$ and $\mathrm{Co}$ species, are the known to be active sites for ORR [8-11]. The utilization of natural clays as support is expected to promote the formation of better pore structures for electrocatalysts prepared from pyrolyzed conductive polymers [15-17].

Among the pyrolysis temperatures investigated in this study, it was found out that pyrolyzed $\mathrm{FeCo} / \mathrm{PANI} / \mathrm{BC}$ prepared at $800^{\circ} \mathrm{C}$ gave the highest current density $\left(\sim 0.71 \mathrm{~mA} / \mathrm{cm}^{2}\right)$. This could be attributed to the generation of more active sites and/or the formation of better pore structures during the pyrolysis process [15-17]. 
It also shows that the clay-based catalysts are more active in alkaline medium with current gain at more negative potentials $[16,17]$. The ORR peak produced by the composite is not the reduced form of PANI because the reduced form is more positive than $-0.4 \mathrm{~V}$ [17]. In the study of Yang and co-workers [15], the cathodic reduction peak of the $\mathrm{Co}(\mathrm{II}) / \mathrm{PANI} / \mathrm{MMT}$ is more negative compared to the commercially available $\mathrm{Pt} / \mathrm{C}$.

Rotating disk electrode (RDE) studies. Rotating disk electrode linear scan voltammetry (RDELSV) was used to determine the reaction pathway for the ORR occurring on each of the electrocatalysts under study. In addition to this, the half-wave potential and current density were determined through the analysis of the voltammetric waves produced. RDE-LSV was done in $\mathrm{O}_{2}$-saturated $0.1 \mathrm{M} \mathrm{KOH}$ solution, using rotation speeds $1000 \mathrm{rpm}, 1500 \mathrm{rpm}$, $2000 \mathrm{rpm}, 2500 \mathrm{rpm}$, and 3000.

In Fig. 2, the voltammetric waves for $\mathrm{FeCo} / \mathrm{PANI} / \mathrm{BC}$ catalyst pyrolyzed at $700^{\circ} \mathrm{C}$, $800^{\circ} \mathrm{C}$, and $900^{\circ} \mathrm{C}$, and $\mathrm{Pt} / \mathrm{C}$ (Premetek) are presented. The calculated current densities (at $\omega=1500 \mathrm{rpm}$ ) of the $\mathrm{FeCo} / \mathrm{PANI} / \mathrm{CB}$ catalyst pyrolyzed at $700^{\circ} \mathrm{C}\left(1.98 \mathrm{~mA} / \mathrm{cm}^{2}\right)$, $800^{\circ} \mathrm{C}\left(3.98 \mathrm{~mA} / \mathrm{cm}^{2}\right)$, and $900^{\circ} \mathrm{C}\left(3.33 \mathrm{~mA} / \mathrm{cm}^{2}\right)$, did not surpass the commercially available $\mathrm{Pt} / \mathrm{C}$ (Premetek) $\left(5.80 \mathrm{~mA} / \mathrm{cm}^{2}\right)$ catalyst activity.

Figure 3A-D shows the LSV profiles and the K-L plots of composites with electrocatalyst pyrolyzed at different temperatures. The current density values at different potentials are plotted against square root of rotation speed as shown in Fig. 3. The data from the graph was used to calculate for the number of electrons transferred according to the Levich equation below.

$$
\frac{1}{j}=\frac{1}{j k}+\frac{1}{j d}=-\frac{1}{n F k C_{O_{2}}^{b}}-\frac{1}{0.62 n F D_{O_{2}}^{2 / 3} v^{-1} C_{O_{2}}^{b} W^{1 / 2}}
$$

Where $j$ is the measured current density, $j_{k}$ is kinetic current density, $j_{d}$ is the diffusion current density, $n$ is the number of electrons transferred per $\mathrm{O}_{2}$ molecule, $k$ is the rate constant for $\mathrm{O}_{2}$ reduction, $F$ is the Faraday constant, $\omega$ is the disk rotation speed, $C_{o_{2}}^{b}$ is the bulk $\mathrm{O}_{2}$ concentration, $D_{o_{2}}$ is the $\mathrm{O}_{2}$ diffusion coefficient, and $v$ is the solution kinematic viscosity [16].

Using Koutechy-Levich analysis, it could be inferred that the ORR process for $\mathrm{FeCo} /$ PANI/BC pyrolyzed at $800^{\circ} \mathrm{C}$ is dominated by the four-electron pathway $(n=3.77)$. This is in contrast to those pyrolyzed at $700^{\circ} \mathrm{C}(n=2.07)$ and $900^{\circ} \mathrm{C}(n=2.78)$, where the ORR process is dominated by the two-electron pathway. Although the magnitude and kinetics of ORR on pyrolyzed $\mathrm{FeCo} / \mathrm{PANI} / \mathrm{BC}$ is found to be inferior relative to $\mathrm{Pt} /$ 

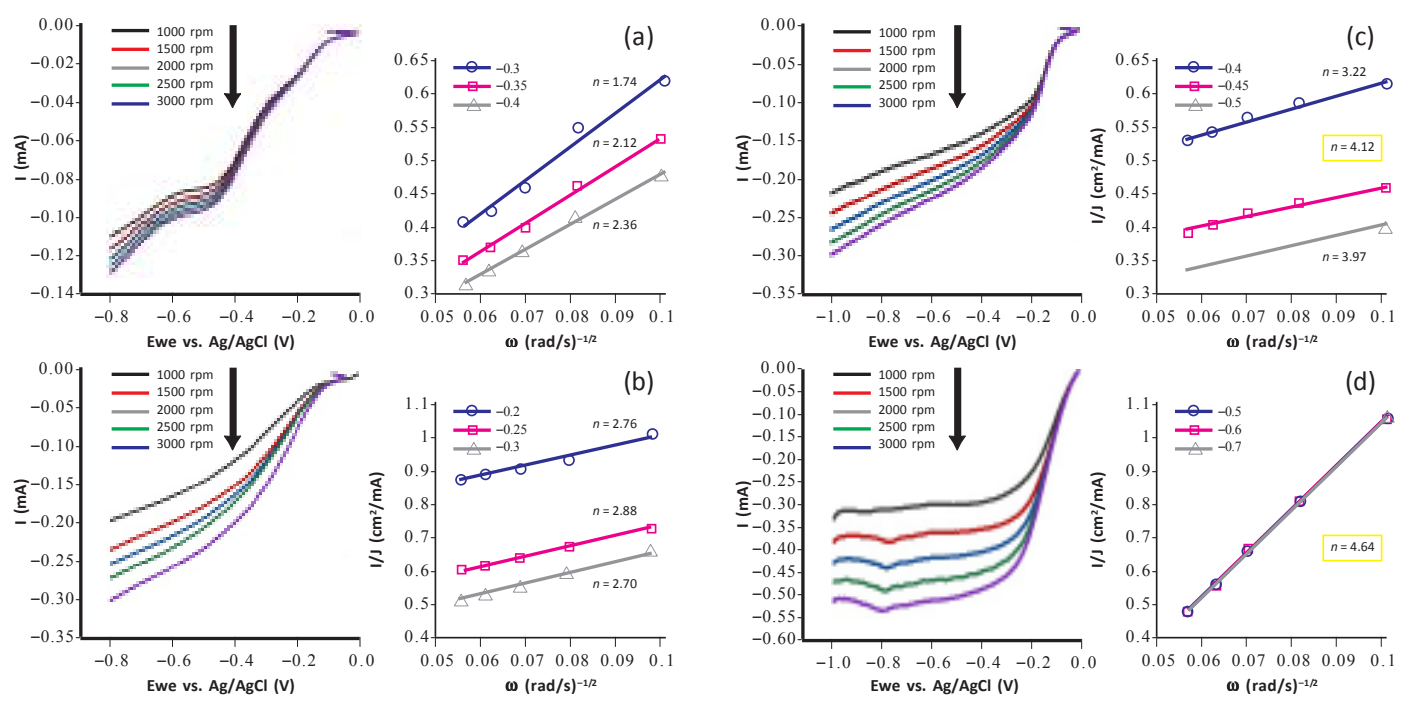

Figure 3. $\mathrm{CV}$ Profiles of $\mathrm{FeCo} / \mathrm{PANI} / \mathrm{CB}$ pyrolyzed at different temperatures: (a) $700^{\circ} \mathrm{C}$; (b) $800^{\circ} \mathrm{C}$; (c) $900^{\circ} \mathrm{C}$ vs. (d) $\mathrm{Pt} / \mathrm{C}$ (Premetek) in $0.1 \mathrm{M} \mathrm{KOH}$ at $50 \mathrm{mV} / \mathrm{s}$ scan rate

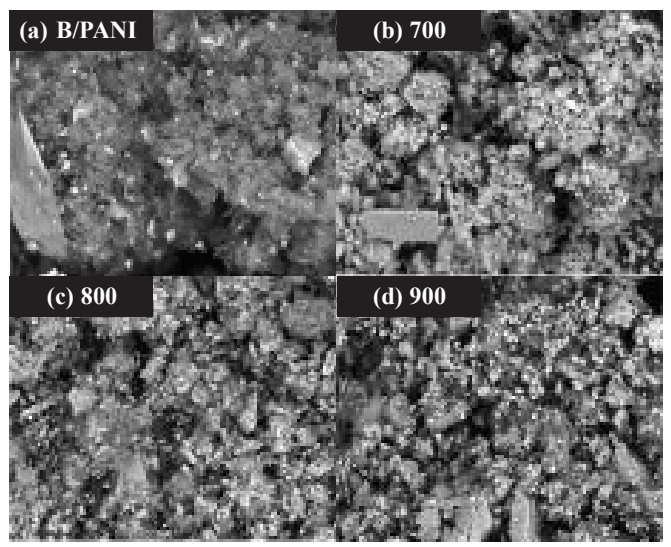

Figure 4. SEM images of (a) non-pyrolyzed $\mathrm{BC} /$ PANI, (b) $700^{\circ} \mathrm{C}$, (c) $800^{\circ} \mathrm{C}$, and (d) $900^{\circ} \mathrm{C}$ pyrolyzed catalyst
$\mathrm{C}$, the results have still been able to show that this electrocatalyst exhibit significant ORR activity, which further opens the possibility for optimization studies.

\section{Scanning electron microscopy (SEM) studies.} The SEM images of non-pyrolyzed BC/PANI (Fig. 4a) at 2000 $\times$ magnification shows a globular and cauliflower-like surface morphology attributed to PANI, and a porous morphology associated with $\mathrm{BC}$ [12-17].

Mineral clays polymerized with conductive polymers have a surface morphology where the clay tends to be fully covered with the polymer. [16] Pyrolyzed catalysts at $700^{\circ} \mathrm{C}, 800^{\circ} \mathrm{C}$, and $900^{\circ} \mathrm{C}$ (Fig. 4B-D) show brighter particles that can be attributed to the Fe and Co particles. Further imaging with the use of EDX and XPS are needed to clearly show the differences in the elemental composition and chemical states of these elemental components of the pyrolyzed catalyst.

In the study of Senerathna and co-workers [17], the conductive polymer when pyrolyzed with the clay can exist both inside and outside of the mineral clay layers. Simultaneously, the metal attached to the clay can also exist both inside and outside the interlayer spaces of the clay $[16,17]$. FE-SEM studies show the layered texture of the carbon-clay composite as well as its porous structure [15]. The nanoparticle size of the metal increases as the temperature is increased [11]. The presence of the 
nitrogen-containing conductive polymers and the metal inside and outside of the clay layers can act as chemically active sites for ORR [16]. The morphology of the composite could possibly assist the ORR process as seen on the CV and RDE data.

The observed ORR activity of the M-N-C catalyst can be attributed to the intercalation of metals, pyrolyzed PANI, and the porous structure of BC forming catalytically active sites. Recent studies [15-17] show higher catalytic activity of catalysts with a different synthesis process. The synthesis involved cation exchange of transition metal with the clay first before undergoing any polymerization process. Thus, the study could further improve its catalytic activity by modifying the synthesis process.

\section{CONCLUSION}

The SEM study of the synthesized BC/PANI support showed porous and globular morphology. Electrochemical characterizations using CV and RDE-LSV for the $\mathrm{FeCo} /$ PANI/BC composite pyrolyzed at $700^{\circ} \mathrm{C}, 800^{\circ} \mathrm{C}$, and $900^{\circ} \mathrm{C}$ revealed the highest current density for the catalyst pyrolyzed at $800^{\circ} \mathrm{C}\left(3.98 \mathrm{~mA} / \mathrm{cm}^{2}\right)$. Though it did not surpass the limiting current density of the Pt/C (Premetek) catalyst $\left(5.80 \mathrm{~mA} / \mathrm{cm}^{2}\right)$, this catalyst is promising and could be a cheaper alternative to Pt-based cathode catalysts for fuel cells.

\section{AcKNowledgment}

This work was funded by the Department of Science and Technology-Accelerated Science and Technology Human Resource Development Program (DOST-ASTHRDP).

\section{REFERENCES}

[1] Serov A \& Kwak C. Recent achievements in direct ethylene glycol fuel cells (DEGFC). Applied Catalysis B: Environmental 2010; 97(1-2), 1-12.

[2] Bashyam R \& Zelenay P. A class of non-precious metal composite catalysts for fuel cells. Nature 2006; 443(7107), 63-66.

[3] Tayal J, Rawat B, \& Basu S. Bi-metallic and tri-metallic Pt-Sn/C, Pt-Ir/C, Pt-Ir-Sn/C catalysts for electro-oxidation of ethanol in direct ethanol fuel cell. International Journal of Hydrogen Energy 2011; 36(22), 14884-14897.

[4] Badwal SPS, Giddey S, Kulkarni A, Goe IJ, \& Basu S. Direct ethanol fuel cells for transport and stationary applications - A comprehensive review. Applied Energy 2015; 145, 80103.

[5] Antolini E. Catalysts for direct ethanol fuel cells. Journal of Power Sources 2007; 170(1), $1-12$.

[6] Mekhilef S, Saidur R, \& Safari A. Comparative study of different fuel cell technologies. Renewable and Sustainable Energy Reviews 2012; 16, 981-989.

[7] Mo Z, Peng H, Liang H, \& Liao S. Vesicular nitrogen doped carbon material derived from $\mathrm{Fe}_{2} \mathrm{O}_{3}$ templated polyaniline as improved non-platinum fuel cell cathode catalyst. Electrochimica Acta 2013; 99, 30-37.

[8] Ren S, Ma S, Yang Y, Mao Q, \& Hao C. Hydrothermal synthesis of Fe2O3/polypyrrole/ graphene oxide composites as highly efficient electrocatalysts for oxygen reduction reaction in alkaline electrolyte. Electrochimica Acta 2015; 178, 179-189.

[9] Ren S, Guo Y, Ma S, Yang Y, Mao Q, Wu D, Jing H, Song X, \& Hao C. Co3O4 nanoparticles assembled on polypyrrole/graphene oxide for oxygen reduction reaction in alkaline media. Chinese Journal of Catalysis 2017; 38(7), 1281-1290. 
[10] Tran TN, Song MY, Singh KP, Yang DS, \& Yu JS. Iron-polypyrrole electrocatalyst with remarkable activity and stability for ORR in both alkaline and acidic conditions: a comprehensive assessment of catalyst preparation sequence. Journal of Materials Chemistry A 2016; 4(22), 8645-8657.

[11] Samad S, Loh, KS, Wong WY, Sudarsono W, Lee TK, \& Daud WRW. Effect of various Fe/ Co ratios and annealing temperatures on a Fe/Co catalyst supported with nitrogen-doped reduced graphene oxide towards the oxygen reduction reaction. Journal of Alloys and Compounds 2020; 816, Art. No. 152573.

[12] Wang R, Jia J, Li H, Wang H, Chang Y, Kang J, \& Lei Z. Nitrogen-doped carbon coated palygorskite as an efficient electrocatalyst support for oxygen reduction reaction. Electrochimica Acta 2011; 56, 4526-4531.

[13] Debnath N, Panwar V, Roy T, Saha M, \& Pal K. Improved dispersion of carbon black in ABS/ PANI blend through its acid functionalization and addition of nanoclay, thereby enhancing mechanical and thermal properties. Polymer Bulletin 2020; 77, 4759-4772.

[14] Rajapakse RMG, Murakami K, Bandara HMN, Rajapakse RMMY, Velauthamurti K, \& Wijeratne S. Preparation and characterization of electronically conducting polypyrrole-montmorillonite nanocomposite and its potential application as a cathode material for oxygen reduction, Electrochimica Acta 2010; 55, 2490-2497.

[15] Yang S, Wu P, Chen L, Huang Z, Liu S, \& Li S. A facile method to fabricate N-doped graphene-like carbon as efficient electrocatalyst using spent montmorillonite. Applied Clay Science 2016; 132(SI), 731-738.

[16] Senarathna KGC, Randiligama HMSP, \& Rajapakse RMG. Preparation, characterization and oxygen reduction catalytic activities of nanocomposites of $\mathrm{Co}(\mathrm{II}) /$ montmorillonite containing polypyrrole, polyaniline or poly(ethylenedioxythiophene). RSC Advances 2016; 6(114), 112853-112863.

[17] Senarathna KGC \& Rajapakse RMG. Silver-montmorillonite-conducting polymer composite materials as low-cost oxygen reduction catalysts. Journal of the National Science Foundation of Sri Lanka 2019; 47(4), 409-420.

[18] Ferrandon M, Wanga X, Kropf J, Myersa D, Wub G, Johnston C, \& Zelenay P. Stability of iron species in heat-treated polyaniline-iron-carbon polymer electrolyte fuel cell cathode catalysts. Electrochimica Acta 2013; 110, 282-291.

[19] Tran TN, Song MY, Singh KP, Yang DS, \& Yu JS. Iron-polypyrrole electrocatalyst with remarkable activity and stability for ORR in both alkaline and acidic conditions: a comprehensive assessment of catalyst preparation sequence. Journal of Materials Chemistry A 2016; 4(22), 8645-8657.

[20] Jiang R \& Chu D. Electrocatalysts for Alkaline Polymer Exchange Membrane (PEM) Fuel Cells - Overview. In: Alonso-Vante N et al. (Eds.) Non-Noble Metal Fuel Cell Catalysts. (Wiley, 2014).

[21] Abdullah NH, Shameli K, Nia PM, Etesami M, Abdullah EC, \& Abdullah LC. Electrocatalytic activity of starch/Fe3O4/zeolite bionanocomposite for oxygen reduction reaction. Arabian Journal of Chemistry 2020; 13(1), 1297-1308. 